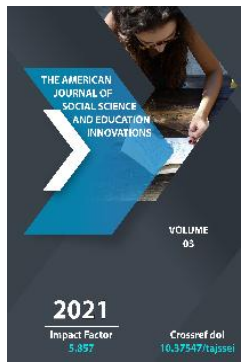

\title{
Primary School Teachers Professiogram
}

Dilorom Mukimovna Tashpulatova

Teacher, Tashkent Regional Chirchik State Pedagogical Institute, Uzbekistan

Journal Website:

http://theamericanjour

nals.com/index.php/taj

ssei

Copyright: Original content from this work may be used under the terms of the creative commons attributes - $1: \ldots . . .-$.

\section{ABSTRACT}

The article discusses the professional profile of primary school teachers and analyzes the approaches in this regard.

\section{KEYWORDS}

Professional, primary education, theoretical knowledge, profile, socialization, orientation, professiogram, culture.

\section{INTRODUCTION}

The development of primary education and the strengthening of its content play an important role in the development of higher education in Uzbekistan. The activity of primary school

teachers in this regard is one of the key factors [1]. Therefore, in recent years, the 
requirements for primary school teachers have been increasing. In this regard, in our opinion, the formation of a professional profile of primary school teachers will give the expected effect.

Professiogram is a sign of professional, theoretical and practical maturity of an individual, which is determined separately for each profession [2]. In this sense, we believe that the professional profile of an elementary school teacher consists of the following:

- Theoretical knowledge;

- Professional maturity;

- Social activity.

The theoretical knowledge of an elementary school teacher is determined by:

- Possession of information;

- Knowledge of the basics of primary education;

- Knowledge of the theory of education;

- Possession of teaching competence.

It is on the basis of these criteria that it is possible to determine the level of theoretical knowledge of an elementary school teacher and identify ways to develop it.

The professional maturity of an elementary school teacher is determined by:

- Knowledge of teaching methods;

- Mastering pedagogical doctrines and theories;
- To have an individual educational method;

- Be able to demonstrate their abilities.

These criteria reflect the professional maturity of the primary school teacher, and based on them, ways to further develop the professional capabilities, experience and activities of teachers are developed.

Today, the social activism of the primary school teacher remains one of the key issues. According to our approach, the basics of social activism of an elementary school teacher are:

- Knowledge of socialization of students;

- Formation of consciousness, concepts of 7-11-year-olds and their formation as a team;

- Orientation of primary school students to ideal goals.

These criteria are an important factor in determining the social activism of primary school teachers and in determining ways to develop their social consciousness, level and culture.

It should be noted that these three issues play a key role in the professional profile of an elementary school teacher. Therefore, it is advisable to pay attention to the following:

- To acquaint future primary school teachers with the basics of professiogram in the process of higher pedagogical education and to form the criteria set in them;

- To acquaint future primary school teachers with the basics, approaches and 
theoretical factors of professiogram, to explain the approaches in this regard;

- To train future primary school teachers to work on themselves;

- Development of a professional profile of primary school teachers in practice through the system of retraining and advanced training of teachers;

- Popularization of the most mature and professional primary school teachers.

This approach is useful in reviewing, monitoring, and monitoring the professional profile of primary school teachers.

Today, the system of primary education in our country is developing in accordance with international standards, and new nongovernmental primary education institutions are emerging in the history of our pedagogy. These two factors could create competition for primary school teachers in the near future. This then leads to the selection of primary school teachers in accordance with the professional and formed professiograms. It is expedient to explain this issue correctly in the process of higher pedagogical education and among primary school teachers in practical activities.

International educational experience shows that in a market economy and in a competitive education system, a consciously and correctly formed professiogram is an important factor in the socio-pedagogical protection of teachers. Therefore, it is advisable to provide well-defined and convenient professiograms in the pedagogical literature, to explain them to future teachers.
In formulating the professional profile of an elementary school teacher, we believe that based on the following will give the expected effect:

- Requirements for education and upbringing, reflected in the national pedagogical heritage;

- State requirements and standards for primary education;

- Social rights, consciousness and worldview of teachers;

- A set of hypotheses, diagnoses and approaches identified in pedagogical research.

It is these fundamentals that come in handy in developing a professiogram of an elementary school teacher that is not so complicated.

It should be noted that each country has developed a professional profile of teachers based on its own mentality and the basis of educational development. In this sense, in our opinion, when developing a professional profile of primary school teachers, it is advisable to pay attention to the following:

- Based on our own national experience in primary education;

- Development of criteria for the professiogram on the basis of the principle of simple to complex;

- Theoretical and practical experience of the developed professiogram;

- To study and take into account the public opinion on the formed professiogram. 
Such an approach will form the basis for the development of a professionally and professionally specific primary school teacher professiogram.

In short, the ongoing development process in our country and the efforts to develop primary education in accordance with international standards increase the need for a fully developed primary school teacher. Therefore, the transition to the training of primary school teachers on the basis of professiograms of scientific and practical experience gives the expected effect. For this purpose, it should be noted that the higher pedagogical educational institutions of the country have gnesological, technological and methodological capabilities. There are also professional professors and teachers in these educational institutions. All of these factors allow the development and implementation of a primary school teacher professiogram.

\section{REFERENCES}

1. Мирзиёев Ш.М. Инсонпарварлик, эзгулик ва бунёдкорлик - миллий ғоямизнинг асосий пойдеворидир. Тошкент, 2021.

2. Бардовская Н. Общая педагогика. Санкт Петербург, 2019.

3. Жабборова О.М. Бошланғич таълимда интеграциялаш масалалари. Academic research in educational sciences. Volume 2, Issue 4, pp. 702-706, 2021.

4. Umarova Z., Jabborova O. Pedagogical conflicts in primary School students - as an important Social-pedagogical problem.//Solid State Technology Volume: 63 Issue: 6Publication Year: 2020. P. 235241.

5. Fariddun Izatulloyevich Ochilov, "Atrofimizdagi olam" va
"Tabiatshunoslik"

darslarini kompetensiyaviy yondashuv asosida tashkil etish jarayonini modellashtirish. The Journal of Academic Research in Educational Sciences, 1(4), (2020). ISSN 2181-1385. VOLUME 1, ISSUE 4. December 2020. Scientific Journal Impact Factor (SJIF) 2020: 4.804. Academic Research, Uzbekistan 2020. - P 624-629.

6. 6. Abdullaeva B.P. Babaraximova B.P. Pardaev B.P.Using information and communication technologies in teaching process of various primary European Journal of Research and Reflection in Educational Sciences, 8 (10), 67-70. Progressive Academic Publishing, UK www.idpublications.org 14.10.2020

7. Abdullaeva B.P. Abdullaeva F.T. Organization Of Swimming Lessons In Preschool Institutions THE AMERICAN JOURNAL OF SOCIAL SCIENCE AND EDUCATION INNOVATIONS. JULY 2020[ TAJSSEI]322ISSN (e):2689-100X DOI: https://doi.org/10.37547/tajssei/Volume02I ssue 07-42

8. Abdullayeva, B. P., \& Babaraximova, B. P. (2020). MAKTABGACHA TA'LIM MUASSASASIDA FUTBOL DARSLARINI TASHKIL ETISH METODIKASI. Academic Research in Educational Sciences http://ares.uz/jurnallar-sahifasi/ares-vol-1no-3-2020

9. ACADEMICIA: An International Multidisciplinary Research Journal https://saarj.com ORGANIZATION AND METHODOLOGY OF CONDUCTING FOOTBALL LESSONS IN A PRESCHOOL INSTITUTION Abdullaeva B.P 650-655 10.5958/2249-7137.2021.00098.7

10. Abdullaeva B.P. Turdalieva M. Corruption in the field of education: assessments and ways to address “Тенденции и 
перспективи развития науки и образования в условиях глобализации".Международной научнопрактической интернет-конференции. г.Переяслав, Украина.2020 год 30 апреля. 58

11. Жабборова О.М., Мамадалиев, К.Р., Абдурахмонова 3.У. Abdullaeva B.P. International Journal of Psychosocial Rehabilitation. DOI: 10.37200/IJPR/V24SP1/PR201199 Received: 17 Jan 2020 | Revised: 07 Feb 2020 | Accepted: 27 Feb 2020 612-619 бет

12. Gulyamova X. Boshlang'ich sinflarda o'qish darsidan umumlashtiruvchi darslarni tashkil etish. Academic research in educational sciences, Volume 2, Issue 1, 2021, pp 1052-1060

13. Жабборова О.М., Умарова 3.А. Тарбия фанини кластер усулида ўқитишда педагогик конфликтларни бартараф этиш. Academic research in educational sciences, Issue 1, 2021, pp 582-587.

14. Жабборова О.М., Чимпулатова Ч.Д. Бошланғич таълимда Тарбия фанининг кластер усулида ўқитилиши. Academic research in educational sciences, Issue 1, 2021, pp 562-566.

15. Жабборова О.М., Ташпулатова А.М. Ўзбекистон янги мафкурасининг педагогик талқини. Academic research in educational sciences, Volume 2, Issue 3, 2021, pp 584-589.

16. Умарова 3.А. Бошланғич таълим дидактикаси. Academic research in educational sciences, Issue 2, 2021, pp 556562.

17. Amaliy mazmunli masalalar asosida iqtisodiy ko'nikmalarni rivojlantirish. NA Beketov. Ilmiy izlanuvchilar va iqtidorli talabalarning maqolalari to'plami, 157-161, 2019
18. Q-многообразия и полные сцепленные системыNA Beketov. Fundamental matematika muammolari va ularning tatbiqlari, 167-169, 2019

19. Кузманова Г.Б., Н.А.Бекетов Use Of Historical Materials In Teaching Mathematics In Continuous Education. The american journal of social science and education innovations, Volume 2 Issue 9, 2020, ISSN 2689-100X, 2(09), 531-537.

20. Кузманова Г.Б.UMUMIY O’RTA TA'LIM MAKTABLARIDA MATNLI MASALALARNING TA'LIMIY AHAMIYATI. ACADEMIC RESEARCH IN EDUCATIONAL SCIENCES, 2(3), 1154-1159

21. Наримбетова З.А ИСПОЛЬЗОВАНИЕ ИНТЕРАКТИВНЫЕ МЕТОДЫ ОБУЧЕНИЯ В УЧЕБНОМ ПРОЦЕССЕ. ЭЛЕКТРОННОЕ НАУЧНО ПРАКТИЧЕСКОЕ ПЕРИОДИЧЕСКОЕ ИЗДАНИЕ http://www.iupr.ru "Экономика и социум" №3(82) 2021 ,МАРТ

22. Ochilov Fariddun Izatulloyevich, Methods of teaching natural sciences to primary school pupils on the basis of a competent. Palarch's Journal Of Archaeology Of Egypt / Egyptology 17(6) (2020), ISSN 1567-214x. - P 14520-14539. 